\title{
Growth and accumulation of nutrients in organic jambu
}

\author{
Leilson Costa Grangeiro'*, Gilberta Carneiro Souto², Valdivia Fátima Lima Sousa', \\ Jader Vieira Carneiro ${ }^{3}$, Jorge Luiz Alves Silva' ${ }^{1}$, Jandeilson Pereira Santos ${ }^{4}$
}

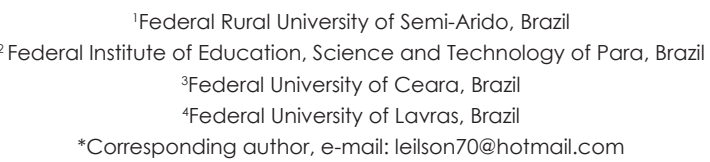

'Federal Rural University of Semi-Arido, Brazil

Federal Institute of Education, Science and Technology of Para, Brazil

${ }^{3}$ Federal University of Ceara, Brazil

${ }^{4}$ Federal University of Lavras, Brazil

*Corresponding author, e-mail: leilson70@hotmail.com

\begin{abstract}
The objective of this study was to evaluate the growth and accumulation of nutrients in accessions of organic jambu. The experiment was conducted in the didactic garden of the Federal Institute of Pará, Campus Castanhal, in the period May and June 2015. The experimental design was a randomized complete block design with a $2 \times 5$ factorial arrangement with four replicates. The treatments were a combination of two jambu accessions (Purple Flower and Yellow Flower) and five sampling times (10, 18, 26, 34 and 42 days after transplanting - DAT). The period of greatest growth and nutrient demand was for access to Purple Flower from 18 to 34 DAT and for the Yellow Flower from 26 to 42 DAT. Nutrient accumulation by the two accesses of jambu, in decreasing order, was: potassium, nitrogen, calcium, magnesium and phosphorus.
\end{abstract}

Keywords: Acmella oleracea, composting, dry matter, plant nutrition

Jambu (Acmella oleracea) is a leafy vegetable which is considered unconventional and is commonly consumed in northern Brazil. This highlight ensures economic importance and currently gives it the status of new vegetable of the tropics, in part due to its success in national and international cuisine and also due to its use in the cosmetics and pharmaceuticals industry (Homma et al., 2011).

Growth curves and nutrient absorption, in relation to the age of the plant, provide information of great importance because us to know the amount of nutrients absorbed and the relative intensity of absorption in each phase of the crop. By examining these curves, the periods

in which the plants absorb the most essential nutrients are shown, providing basic information on the best times for fertilizer application. However, the amount of nutrients absorbed vary according to the cultivar and the soil and climate conditions, such as soil fertility, type of soil management, temperature and rainfall (Mendoza-Cortez et al., 2013; Aquino et al., 2015).

The nutrient content of the plant may be used to estimate the amount of nutrients taken up and exported by the crop. These values are essential in establishing an effective fertilization system (Sharma et al., 2012).

In Brazil, information on nutrient absorption by the jambu crop is scarce. Borges 
et al. (2013a) evaluated the accumulation of nutrients by jambu as a function of fertilization with manure and urea. Fertilization with urea favored higher accumulation of $\mathrm{N}$ in the leaves (612.94 $\mathrm{mg} \mathrm{plant}^{-1}$ ) and inflorescences (310.06 mg plant $^{-1}$ ). However, fertilization with manure provided greater accumulation of $\mathrm{P}, \mathrm{K}, \mathrm{Ca}, \mathrm{Mg}$ and $S$ in the leaves $(72.15 ; 689.28 ; 81.43 ; 32.09$ and $51.03 \mathrm{mg}$ plant ${ }^{-1}$, respectively) and in the inflorescences $(71.98 ; 350.75 ; 31.64 ; 26.72$ and $25.04 \mathrm{mg} \mathrm{plant}^{-1}$, respectively). In this context, the objective of the present study was to evaluate the growth and accumulation of nutrients in accessions of organic jambu.

The experiment was carried out in field conditions at the Instituto Federal do Pará located in the municipality of Castanhal ( $1^{\circ} 17^{\prime}$ $46^{\prime \prime}$ S, $47^{\circ} 55^{\prime} 28^{\prime \prime}$ W and altitude of $41 \mathrm{~m}$ ), Pará state, Brazil, from May to June 2015. Chemical analysis of soil samples from the experimental area, taken at depths of between 0 and $20 \mathrm{~cm}$, showed the following results: $\mathrm{pH}\left(\mathrm{H}_{2} \mathrm{O}\right)=6.5$; $\mathrm{P}_{\text {(menlich }^{-1} \text { ) }}=277.34 \mathrm{mg} \mathrm{dm}^{-3} ; \mathrm{K}=24.34 \mathrm{cmol}_{\mathrm{c}} \mathrm{dm}^{-3}$; $\mathrm{Ca}=3.60 \mathrm{cmol}_{\mathrm{C}} \mathrm{dm}^{-3}, \mathrm{Al}=0.10 \mathrm{cmol}_{\mathrm{C}} \mathrm{dm}^{-3} ; \mathrm{H}+\mathrm{Al}$ $=1.3 \mathrm{cmol}_{\mathrm{c}} \mathrm{dm}^{-3}$ and organic matter $=21.5 \mathrm{~g} \mathrm{~kg}^{-1}$. The climate of the region, according to Köppen, is of Af type, namely equatorial humid (Bastos, 1972). From May to June, precipitation was 214.4 $\mathrm{mm}$, and the mean maximum, minimum and average temperature were $33.4 ; 22.3$ and 26.6 ${ }^{\circ} \mathrm{C}$, respectively.

The experimental design was randomized complete block with a $2 \times 5$ factorial scheme and four replicates. The treatments resulted from the combination of two jambu accessions (Purple Flower and Yellow Flower) and five sampling times $(10,18,26,34$ and 42 days after transplanting DAT). Each experimental unit consisted of a $3.0 \mathrm{x}$ $1.0 \mathrm{~m}$ plot, with five rows of plants, spaced at 0.20 $\times 0.20 \mathrm{~m}$, making a total area of $3.0 \mathrm{~m}^{2}$. The three central rows were considered to be the useful area.

The organic fertilizer consisted of a mixture of organic compost and vermicompost. The organic compost was prepared with dry leaves (mixture of leaves from Syzygium malaccense, Inga edulis, Mangifera indica and Zoysia japonica) and bovine manure at a ratio of 3:1 by volume. The vermicompost used came from the production of California red earthworms (Eisenia foetida Savigny) based on bovine manure. The mixture of the organic compost and vermicompost was prepared at a ratio of 1:1 by volume. The chemical composition of the organic fertilizer after mixing was as follows: $\mathrm{pH}$ $=6.2 ; \mathrm{C} / \mathrm{N}$ ratio $=13 / 1$; humidity $=40 \%$; organic matter $=18.5 \%$; and (in $\left.\mathrm{g} \mathrm{kg}^{-1}\right) \mathrm{N}=8.0 ; \mathrm{P}=3.4 ; \mathrm{K}$ $=2.1 ; \mathrm{Ca}=7.7 ; \mathrm{Mg}=2.7 ; \mathrm{S}=2.3 ; \mathrm{C}=102.7$ and in $\mathrm{mg} \mathrm{kg}^{-1}: \mathrm{Fe}=3115 ; \mathrm{Cu}=22 ; \mathrm{Mn}=181 ; \mathrm{Na}=534 ;$ $\mathrm{Zn}=98$ and $\mathrm{B}=7$.

Sowing was conducted in 128-cell polystyrene trays containing vermicompost, placing ten seeds per cell. After germination of the seeds, thinning was performed, leaving five plants per cell. Seedlings were transplanted to the field 30 days after sowing, using a spacing of $0.20 \times 0.20 \mathrm{~m}$ and up five plants per hole (plant bunch).

Soil preparation consisted of harrowing followed by lifting of the beds. Fertilization at planting was carried out using half the dose of organic fertilizer $\left(10 \mathrm{~kg} \mathrm{~m}^{-2}\right)$ distributed on the surface of the bed with subsequent incorporation the top 5-cm layer. The other half was applied on the surface in two equal quantities at 10 and 20 days after transplantation (DAT) of the jambu.

In each collection time, two plant bunches (containing five plants each) were used per replicate. After each collection, the plants were washed in running water, distilled water with neutral detergent $(1 \mathrm{~mL})$ and deionized water (in that sequence), and dried in a forced air circulation oven at $65{ }^{\circ} \mathrm{C}$ until reaching a constant mass. As a function of the amount of dry matter of the samples, the dry matter accumulation was determined at each sampling time (with the results expressed in mg per bunch). The samples were then processed in a Willey ${ }^{\circledR}$ mill ( $2 \mathrm{~mm}$ sieve) and packed in closed containers.

Chemical analysis was carried out on extracts obtained using sulfuric ( $N$ ) and using nitric-perchloric (P, K, Ca and Mg). Nitrogen was quantified using the Kjeldahl semi-micro method, phosphorus using the phosphomolybdic complex method with reducing medium, potassium by flame emission photometry, and other nutrients by atomic absorption spectrophotometry (Embrapa, 2009). The results of the analysis 
provided nutrient concentrations (N, P, K, Ca and $\mathrm{Mg}$ ) and to determine the amounts accumulated, the concentration of each nutrient was multiplied by the dry matter of each plant bunch at each sampling time.

The data were submitted to analysis of variance using SISVAR software (Ferreira, 2011) and regression analysis using Tablecurve software (Jandel Scientific, 1991).

The productivity of the accessions of Purple Flower and Yellow Flower jambu were 2.29 and $2.38 \mathrm{~kg} \mathrm{~m}^{-2}$, respectively. These values were within the range of average values of the state of Pará, which is 1.8 to $3.0 \mathrm{~kg} \mathrm{~m}^{-2}$ according to Rodrigues et al. (2014).

Jambu plant growth, expressed in terms of dry matter accumulation, was slow up to 18 DAT, intensifying after this time. In this period, the dry matter represented 17\% (Purple Flower) and $5 \%$ (Yellow Flower) of the total accumulated by the plant. In the periods of greatest accumulation, which occurred from 18 to 34 DAT for Purple Flower and 26 to 42 DAT for Yellow Flower, the accessions accumulated 73 and $81 \%$, respectively, of the total dry matter accumulated by the plant (Figure 1).

This behavior is common in some leafy vegetables (especially those with short growth cycles), which initially present a slow phase of accumulation of dry matter, intensifying at the end of the cycle. As observed in lettuce (GRANGEIRO et al., 2006), arugula and coriander (GRANGEIRO et al., 2011 ). The estimated maxima were 6090.37 and $8009.81 \mathrm{mg}$ plant bunch-1 for the Purple Flower and Yellow Flower, respectively, obtained at 42 DAT (Figure 1).

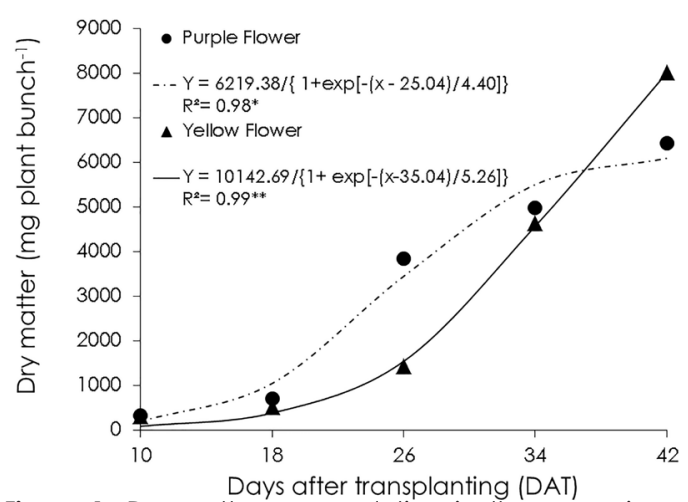

Figura 1. Dry matter accumulation in the accessions of jambu Purple Flower $(\bullet)$ and Yellow Flower $(\boldsymbol{\Delta})$ as a function of the transplant period. Castanhal-PA, 2015.

With the Purple Flower access, the increase in dry matter content in the period 18 to 34 DAT was $278.54 \mathrm{mg} \mathrm{day}^{-1}$, higher than the $98.16 \mathrm{mg} \mathrm{day}^{-1}$ observed in the period which followed (36 to 42 DAT). This was also greater than the $105.92 \mathrm{mg} \mathrm{day}^{-1}$ obtained in the 10 to 18 DAT period. With the Yellow Flower, the rate increase in dry matter in the period of highest growth (26 to 42 DAT) was $486.28 \mathrm{mg} \mathrm{day}^{-1}$, higher than the $37.04 \mathrm{mg} \mathrm{day}^{-1}$ verified from 10 to 18 DAT and $144.97 \mathrm{mg} \mathrm{day}^{-1}$ from 18 to 26 DAT.

The amount of $\mathrm{N}, \mathrm{P}, \mathrm{K}, \mathrm{Ca}$ and $\mathrm{Mg}$ accumulated during the jambu growth cycle showed similar trends to dry matter accumulation, ie, 18 DAT. Macronutrient accumulation in the two accesses, in decreasing order, was: K, N, Ca, $M g$ and $P$.

The accessions Purple Flower and
Yellow Flower accumulated 207.55 and 286.85 mg $\mathrm{N}$ plant bunch-1, respectively. The highest $\mathrm{N}$ accumulation occurred from 18 to 34 DAT (Purple flower) and 26 to 42 DAT (Yellow flower) (Figure 2). The accumulated $N$ quantities were small in the initial stages, with mean increments of 3.62 and $1.52 \mathrm{mg} \mathrm{day}^{-1}$ in the period from 10 to 18 DAT for the accesses Purple Flower and Yellow Flower, respectively. In the phase of greatest accumulation, the rate of increase was 10.60 and $16.14 \mathrm{mg} \mathrm{day}^{-1}$, for Purple Flower and Yellow Flower, respectively (Figure 2). As observed for dry matter, the Yellow Flower also accumulated greater amounts of $\mathrm{N}$.

In leafy vegetables, the provision of adequate doses of nitrogen favors vegetative development, expands the photosynthetically active area and increases the productive 
potential (Borges et al., 2013b).

Phosphorus was the nutrient accumulated in the lowest quantity by jambu plants, with a maximum of 39.23 and $49.62 \mathrm{mg}$ plant bunch ${ }^{-1}$ reached at 42 DAT in the Purple Flower and Yellow Flower, respectively (Figure 2). The highest demand for $\mathrm{P}$ occurred the period 18 to 34 DAT (Purple Flower) and 26 to 42 DAT (Yellow Flower), with estimated accumulation rates of 1.90 and $3.00 \mathrm{mg} \mathrm{day}^{-1}$.
Potassium was the nutrient accumulated in the highest quantity by the accesses of jambu, similar to results reported by Borges et al. (2013a). The maximum $\mathrm{K}$ accumulations were 410.56 and $434.36 \mathrm{mg} \mathrm{plant} \mathrm{bunch}^{-1}$ for the Purple Flower and Yellow Flower jambu, respectively (Figure 2). Up to 18 DAT, the accumulation of $\mathrm{K}$ represented $16 \%$ (Purple Flower) and $5 \%$ (Yellow Flower) of the total amount of $\mathrm{K}$ accumulated.
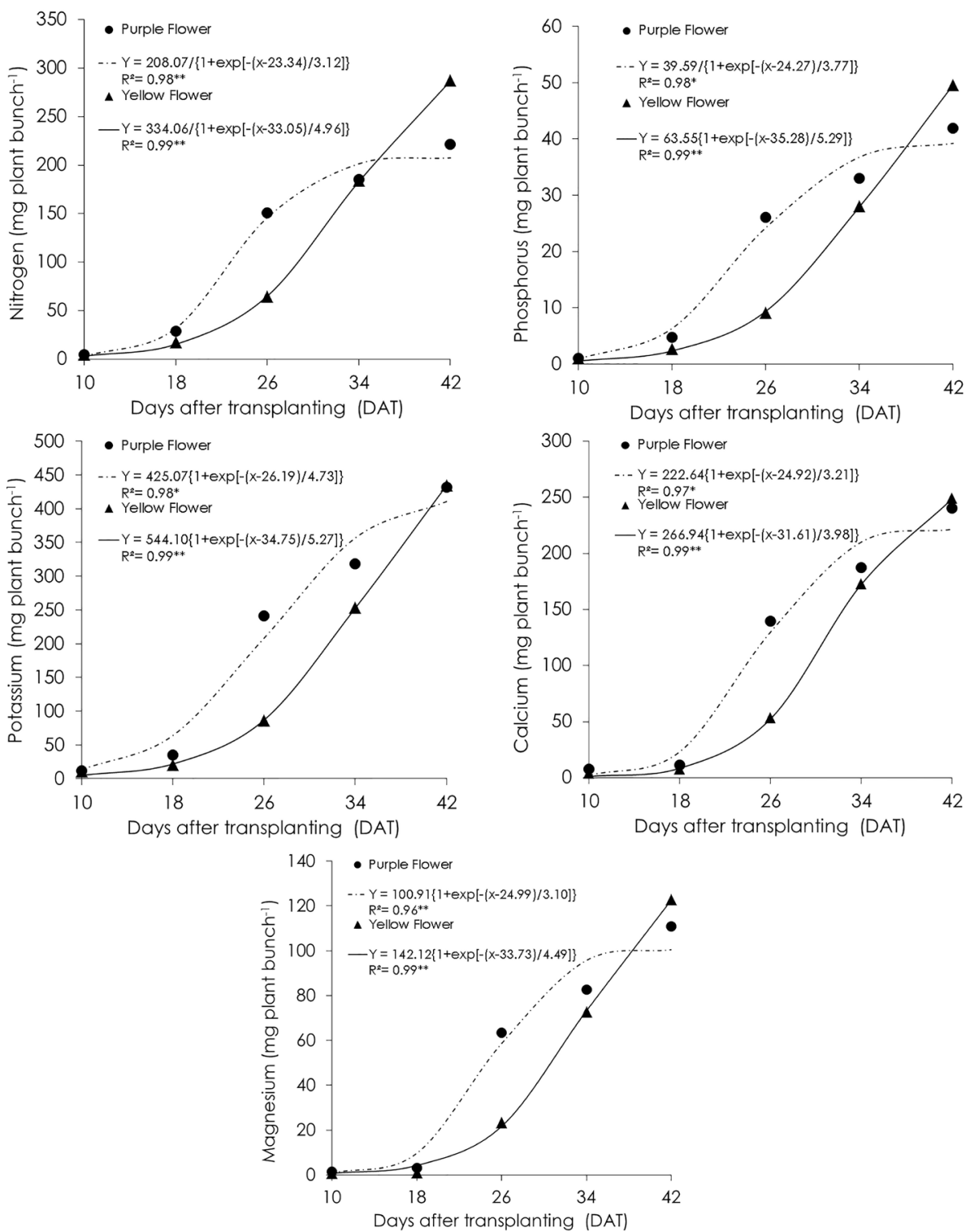

Figura 2. Nitrogen, phosphorus, potassium, calcium and magnesium accumulation in jambu Purple Flower $(\bullet)$ and Yellow Flower $(\boldsymbol{\Delta})$ as a function of the transplant period. Castanhal-PA, 2015.

In the Purple Flower access, the daily accumulation rate of $\mathrm{K}$ in the period between 18 and 34 DAT was $18.29 \mathrm{mg} \mathrm{day}^{-1}$, higher than the $6.74 \mathrm{mg}$ day $^{-1}$ observed in the subsequent period (36 to $42 \mathrm{DAT}$ ), and also greater than the
$6.31 \mathrm{mg} \mathrm{day}^{-1}$ reported in the 10 to 18 DAT period. In the Yellow Flower, the rate of increase in the period of greatest demand (26 to 42 DAT) was $21.71 \mathrm{mg} \mathrm{day}^{-1}$, higher than the $2.10 \mathrm{mg} \mathrm{day}^{-1}$ verified from 10 to 18 DAT and $8.14 \mathrm{mg}$ day $^{-1}$ from 
18 to 26 DAT. Potassium was also the nutrient that accumulated the most in other leafy vegetables, such as lettuce (Kano et al., 2011), coriander and arugula (Grangeiro et al., 2011).

The maximum calcium accumulation was 221.56 and $248.66 \mathrm{mg}$ plant bunch-1 for $^{-1}$ the Purple Flower and Yellow Flower accesses, respectively, reaching 42 DAT (Figure 2). The highest demand occurred in the same period observed for the other nutrients, coinciding with the greater accumulation of dry mass by the plant.

Borges et al. (2013a) observed greater accumulation of $\mathrm{Ca}$ in the leaves compared to the inflorescences of jambu, regardless of the source of fertilizer (organic or mineral). With organic fertilization, mean values were 81.34 and $31.64 \mathrm{mg} \mathrm{plant}^{-1}$ in leaves and inflorescences, respectively.

The accumulation of $\mathrm{Mg}$ increased with time in both accessions, reaching a maximum value at 42 DAT. The maximum accumulation of Mg was 100.49 and 122.60 mg plant bunch ${ }^{-1}$ for Purple Flower and Yellow Flower, respectively. The highest demand occurred in the period 18 to 34 DAT (Purple Flower) and 26 to 42 DAT (Yellow Flower), with estimated accumulation rates of 5.38 and $6.3 \mathrm{mg} \mathrm{day}^{-1}$.

At the planting density used $(250,000$ plant bunches per hectare), nutrient extraction for Purple Flower was: $34.8 \mathrm{~kg} \mathrm{ha}^{-1}$ of $\mathrm{N} ; 6.6 \mathrm{~kg} \mathrm{ha}^{-1}$ of $P ; 68.8 \mathrm{~kg} \mathrm{ha}^{-1}$ of $\mathrm{K} ; 37.1 \mathrm{~kg} \mathrm{ha}^{-1}$ of $\mathrm{Ca}$ and 16.8 $\mathrm{kg} \mathrm{ha}^{-1}$ of Mg. Values for Yellow Flower were: 48.0 $\mathrm{kg} \mathrm{ha}^{-1}$ of $\mathrm{N} ; 8.3 \mathrm{~kg} \mathrm{ha}^{-1}$ of $\mathrm{P} ; 72.7 \mathrm{~kg} \mathrm{ha}^{-1}$ of $\mathrm{K} ; 41.6$ $\mathrm{kg} \mathrm{ha}^{-1}$ of Ca and $20.53 \mathrm{~kg} \mathrm{ha}^{-1}$ of $\mathrm{Mg}$.

The period of greatest growth and nutrient demand in Purple Flower was from 18 to 34 DAT and in Yellow Flower from 26 to 42 DAT. Nutrient accumulation by the two accessions of jambu, in decreasing order, was: potassium, nitrogen, calcium,

\section{References}

Aquino, R.F.B.A., Assunção, N.S., Aquino, L.A., Aquino, P.M., Oliveira, G.A., Carvalho, A.M.X. 2015. Nutrient demand by the carrot crop is influenced by the cultivar. Revista Brasileira de Ciência do Solo 39: 541-552.

BASTOS, T.X. 1972. O clima da Amazônia brasileira segundo Koppen. Belém, IPEAN. B. Técnico, v.54, p.68-122.

Borges, L.S., Goto, R., Guerrero, A.C. $2013 a$. Exportação de nutrientes em plantas de jambu, sob diferentes adubações. Semina: Ciências Agrárias 34:107-1 16.

Borges, L.S., Guerrero, A.C., Goto, R., Lima, G.P.P. 2013b. Produtividade e acúmulo de nutrientes em plantas de jambu, sob adubação orgânica e mineral. Semina: Ciências Agrárias 34: 83-94.

Embrapa. Empresa Brasileira de Pesquisa agropecuária. 2009. Manual de análises químicas de solos, plantas e fertilizantes. 2.ed. Brasília, DF : Embrapa Informação Tecnológica, 2009. 627 p

Ferreira, D. F. 2011. SISVAR: A Computer statistical analysis system. Ciência e Agrotecnologia 35: 1039-1042.

Grangeiro, L.C., Costa, K.R., Medeiros, M.A., Salviano, A.M., Negreiros, M.Z., Bezerra Neto, F., Oliveira, S.L. 2006. Acúmulo de nutrientes por três cultivares de alface cultivadas em condições do Semi-Árido. Horticultura Brasileira 24: 190-194.

Grangeiro, L.C., Freitas, F.C.L., Negreiros, M.Z., Marrocos, S.T.P., Lucena, R.R.M., Oliveira, R.A. 2011. Crescimento e acúmulo de nutrientes em coentro e rúcula. Revista Brasileira de Ciências Agrárias 6: 11-16.

Homma, A.K.O., Sanches, R.S., Menezes, A.J.E.A., Gusmão, S. A. 2011. Etnocultivo do jambu para Abastecimento da cidade de Belém. Amazônia: Ciência e Desenvolvimento 6: 125-141.

Jandel Scientific. Table curve: curve fitting software. Corte Madera, CA: Jandel Scientific, 1991, 280p.

Kano, C.; CARDOSO, A. I. I.; VILLAS BÔAS, R. L. Acúmulo de nutrientes pela alface destinada à produção de sementes. Horticultura Brasileira, Brasília, v. 29, n. 1, p. 70-77, 2011.

Mendoza-Cortez, J.W., Cecílio-Filho, A.B., Rosa, M.O., Nascimento, C.S. 2013. Growth of potato plants of the 'Asterix' cultivar and accumulation of nutrients. Journal of Agricultural Science 5: 217226.

Rodrigues, D.S., Camargo, M.S., Nomura, E.S., Garcia, V.A., Correa, J.N., Vidal, T.C.M. 2014. Influência da adubação com nitrogênio e fósforo na produção de jambu, Acmella oleracea (L) R. $K$. Jansen. Revista Brasileira de Plantas Medicinais 16: 71-76.

Sharma, K.D., Karks, S., Thakur, N.S., Attri S. 2012. Chemical composition, functional properties and processing of carrot - a review. Journal Food Science Technologyc 49: 22-32. 